\title{
The developing speciality coffee businesses of Bangkok, Thailand and Penang, Malaysia. A story of entrepreneurial passion and creativity?
}

\section{Mark Azavedo ${ }^{1}$ iD and Art Gogatz ${ }^{2}$}

\begin{abstract}
Purpose: This paper considers the recently emergent speciality coffee industry in Bangkok, Thailand and Penang, Malaysia. It addresses the research questions of what are the motivations and attitudes of small, entrepreneurial, speciality coffee business owners in both countries. Methodology: The study's methodology was interview-based qualitative data gathering with no pre-determined hypotheses. Interviews were semi-structured. Questions considered motivations and attitudes variously but particular points of focus were passion and creativity. Analysis was through thematic content analysis. Findings: The main findings were that participants considered themselves to be passionate and creative, wanted to educate about coffee (the primary finding) and have no expectation and little hope of becoming wealthy through their coffee enterprises. Their focus was on other elements of happiness than money. It transpired that their passion was not an entrepreneurial passion, financially driven, but a passion for craft skills and production, and attendant lifestyles that were simply not concerned about income maximisation. Implications for theory and practice: It presents a potential view of entrepreneurship at major variance with the views of classical economics. Few entrepreneurs interviewed saw their businesses as having potential for wealth creation. Concerns to maximise income or profit were not prevalent. These were not the financially driven entrepreneurs of classical economics. Their focus was on their craft and its skills. All understanding of the mindset of the small speciality coffee business owners and creators is an insight of substantial practical importance, for instance, to those seeking to supply to them and perhaps other similar small businesses, or to advise them, including Government and Local Government advisory services. Originality and value: The question set for

1 Mark Azavedo, Ph.D. student, Shinawatra University, School of Management, Shinawatra University Bangkok Center, BBD Building, 197 Viphavadi-Rangsit Road, Samsen Nai, Phaya Thai, Bangkok 10400, Thailand, e-mail: markazavedo@ yahoo.co.uk (ORCID: https://orcid.org/0000-0002-3750-5729).

2 Art Gogatz,, Associate Professor, Phayao University, College of Management, 55 Wave Place Building, Wireless Road, Bangkok 10330, Thailand, e-mail: gogatz@yahoo.com (ORCID: https://orcid.org/0000-0003-3200-8085).
\end{abstract}


this study had never been asked before, so the study is unique within the industry. Its value lies in two areas, the practical real world of business, as mentioned, and for future researchers in entrepreneurship. With these small businesses built from lifestyle concepts rather than classical economic concepts, notably of income or profit maximisation and scale appropriate to those, strong doubt is thrown on the validity of those classical economic views. An important value in this study is precisely that it drilled down and struck a plethora of motivations and attitudes informally held by entrepreneurs, people of a type that do not usually inform studies of entrepreneurship but may inform future researchers, particularly when reviewing the growing body of small artisanal and craft businesses.

Keywords: passion, creativity, speciality coffee, craft businesses, entrepreneurship, craft skills, small business

\section{INTRODUCTION}

Research undertaken in 2019 considered the speciality coffee industry in Penang, Malaysia, and Bangkok, Thailand. Both countries are neighbours within ASEAN, and have long histories of coffee production. The research questions were what motivates the entrepreneurs in the new speciality coffee industry and what are their attitudes? The background is that it would be easy to assume there is little space within the market for new entrants. Starbucks, for instance is ubiquitous. Saying that though assumes normal commercial motivations by the newcomers. In fact, though their motivations may not be strictly commercial but more akin to those of say craft beer makers (Watne, Hakala, \& Kautonen, 2012), driven by passion and/or the desire to express their creativity. Passion and creativity became main drivers in the researchers' consideration of the speciality coffee entrepreneurs and were likely the main drivers in their entry into the marketplace, but no formal hypotheses were made. The participants were to speak for themselves in a qualitative survey. Speciality coffee entrepreneurs had not received such research attention before, and this despite coffee having a long history that was both passion-filled and highly creative, giving to posterity say The London Stock Exchange and Lloyds of London, the insurance market place.

\section{Early coffee entrepreneurialism}

Arguably, since the earliest days of coffee, possibly around AD 850 (Nzegwu, n.d.), its story has been one of entrepreneurial passion and creativity and, thence, the development of commercial acumen or adaptation of it to the specifics of coffee supply chains. 
Claims to be the originator of coffee lay with both Ethiopia and Yemen. Perhaps the Ethiopian foundation story is the most often repeated. It involves the story of Kaldi, a goatherd who noticed his goats were more alert and frisky after chewing berries from a particular plant. Kaldi involved a local monastery. The monks perfected brewing from the berries and, thereby, coffee was born complete with the monks as brand ambassadors to press its case.

Yemen has two coffee-origin narratives (Goodwin, 2019). One is similar to the story of Kaldi, except this time excited birds were seen. The second Yemeni narrative is based around Sheikh Omar, a doctor-priest from Mocha, who had been exiled. Close to starvation, he tried the red coffee cherries to caffeinated effect. The story of Omar and his revitalising beverage reached Mocha, his exile was lifted and he returned to the city. Coffee came to be regarded as a miraculous curative and became a major export of Mocha, a port city. Coffee bean was grown in Yemen and land-based export routes also developed from Yemen into South Asia, about the Middle-East and also into Europe ("History of Coffee"). By the seventeenth century coffee was establishing in Europe.

England, particularly London, arguably became best known for the coffee shops as "penny universities" ("The History of Coffee"), places for highly erudite conversation, perhaps political or philosophical. However, they also had an innovative commercial side as places to develop and transact business. London coffee houses of the seventeenth century spawned the stock exchange, insurance industry (Lloyds) and auctioneering (Green, 2013). They were a significant London presence with around 550 coffee houses (Inwood, 1998).

In Holland, coffee was considered more as a traded commodity than a beverage. The early coffee houses in Holland were highly associated with business, and particularly located in business areas of Dutch cities (Arat, n.d.). Financial products developed early as adjuncts to or derivatives from the trading, creating the class of merchant bankers.

\section{Coffee entrepreneurialism in the twentieth and twenty-first centuries}

Profound innovation struck the coffee retail industry in the early twentieth century with the advent of the espresso machine, first produced in 1905 (Morris, 2008). This enabled preparation of coffee for individual customers. Previously coffee could only be batch prepared. The Gaggia Classic Espresso machine of 1948, allowed the production of crema under the pressure of nine atmospheres (Morris, 2007). Additionally, frothy coffee such as cappuccino or latte was possible using milk and the espresso machine's steam wand.

Coffee's more recent history has been seen in terms of waves. The First Wave refers to the commoditisation of coffee, but, in fact, for home 
consumption, using commodity bean, processed for easy and speedy use in the home. "Instant" was perhaps a bye-word. Association may be made with, for example, Maxwell House and Nescafe. The Second Wave marked a change of location focus to coffee shops, accompanied by a marked uptrend in quality and variety of beverages available, even if from a coffee base, usually espresso. Starbucks typifies this coffee phase.

Moving forward, arguably, to the present and the advent of the Third Wave, there is confusion. That includes whether the coffee industry has now reached a Fourth Wave. Many characteristics are suggested, for instance concerning the rise of scientific understanding and technological improvement, maybe in roasting or water treatment for consistency. Equally, the Third Wave may be seen in terms of very high standards of presentation or customer service. There might also be concern for the supply chain, "from farm to cup," and for its sustainability and equity.

Ultimately, the balance lies between individuals and nationalities. In, arguably, highly nationalistic Thailand, it is very usual to find roasters and coffee-shop owners who are deeply concerned about promoting local coffee and coffee farmers. This is not found in Malaysia. Across both Thailand and Malaysia, this study found huge concern for customer service. On the other hand, a visit to perhaps the world's most technical roaster, Tim Wendelboe, in Oslo, produced the comment “... but I missed a bit of customer service here. The girl helped me as fast as possible, so she could do her other tasks" (Giljam, 2018).

The researchers' conclusions are that if the specialty coffee industry is moving toward a Fourth Wave or has reached it, that may increasingly be seen in terms of technical process at the farm. Innovations there though are often in collaboration with middlemen and roasters further down the supply chain. There may be both technical and financial input. "From farm to cup" supply chain cohesion is ever more a reality and is one promoting sustainability and equity across the supply chain.

All this said, the involvement of the Third Wave in presentation must not be underestimated. That may mean presentation of the coffee, for instance to include latte art, but also presentation of the premises. Theng (2018) looks to both interiors and often exteriors of premises and speaks of a range of presentational ploys, stylistic choices by way, for instance, of materials, typography and monochrome "colour" palettes, the messaging of which mean that an independent Third-Wave coffee shop cannot be missed. Both presentation of the premises and the coffee is likely to have an eye to being picture-worthy for Instagram, a major attractant of customers in the food and beverage industries (e.g. Churchard, Townshend, \& Stone, 2018). Johnson (2019) has been specific about the coffee industry extolling Instagrammability 
and offering creative backdrops for the Instagram photographer from feature walls to coffee's technical equipment.

This study found participants very divided on Instagram, some for, some against, others seeing it, reluctantly, as a marketing necessity, particularly in the early days of a business in the internet, and specifically social media, age.

\section{Speciality coffee entrepreneurship}

Notwithstanding the foregoing, the defining element in coffee's Third Wave is speciality coffee sale, the determining factor to be a participant in this study, the research questions of which were what are the motivations and attitudes of small speciality coffee business owners in Bangkok and Penang.

Speciality coffee is defined by a Specialty Coffee Association of America cupping value of 80 points and above. In reality, other characteristics are associated with speciality coffee, most notably the Arabica coffee bean, but also, for example, single origin, multiple national origins, traceability and possibly light to medium roasting might be considered, together with a proliferation of methods of brewing, such as V60, Aeropress and siphon.

Behind that key element, in the speciality coffee business, lies another key, attitudes and motivations of individual coffee shop and roaster entrepreneurs, though perhaps as important, aligning with the work of, for example, Bhansing, Hitters and Wingaarden (2017), is those entrepreneurs operating in a supportive environment. That environment may include the support of other entrepreneurs in the same or cognate industries in a corpus of "localised passion" (Bhansing et al., 2017). Bhansing et al. (2017) considered co-location in Creative Business Centres, but maybe location does not have to be physically as proximate as that, with relevant networks building within the industry, say in a city or across a number of centres within a region. That certainly appears true within speciality coffee. In Bangkok and Penang, everybody seems to know everybody else. They are supportive of each other. The researchers also found substantial connectedness between Bangkok and Penang, and could adopt snowball sampling between the two. In Penang, two speciality coffee shops have worked jointly to send the clients of both shops off on a long weekend trip to a Malaysian coffee-growing region. Perhaps it is important to consider that not only do the entrepreneurs have a shared passion for coffee, as they say, but much wider shared attitudes than just in business are likely. For instance, as a tight millennial grouping (see demographics for participants below), they are likely to be highly attuned to collaborative working and efforts (e.g., Simpson, n.d.). 


\section{LITERATURE REVIEW}

The literature review was immediately limited by a lack of relevant coffeeindustry academic literature, meaning studies of speciality coffee and artisanal coffee production. There has been much academic research on coffee's First Wave. There are 377 Google Scholar entries for Nescafe and Maxwell House, who offer instant home coffee-making products. Even where speciality coffee products are used at home they require special equipment for both pour and espresso and require high levels of skill from the operator. There has been even more research on coffee's Second Wave. There are 131,000 Google Scholar entries on Starbucks alone. Starbucks is currently a chain of 24,000 shops. Oden (n.d.) has considered the differences between Starbucks and speciality coffee shops. A key is Starbucks' vast scale and speed of growth. Of necessity that scale produced an undiscriminating delving into the bean supply chain and one that favours consistency over quality. Relatively dark roasting was adopted to mask differences and create a uniform flavour profile. This fitted not only supply-side demands but marketing ones in that the Starbucks niche was perceived as mass-market avoiding specific flavour notes and so becoming a brand for coffee snobs. People do not go into Starbucks to discuss the finer points of Costa Rica's composer series or to taste Mozart, Beethoven or Bach. Starbucks is the antithesis of speciality coffee businesses and as such information on it is irrelevant when researching speciality coffee. Perhaps the narrative can be simplified to one of uniformity (Starbucks) versus passion, creativity and difference, even quirkiness, from the speciality coffee shops and coffee roasters.

Maybe the uniformity of Starbucks and the quirkiness of individual owners and roasters are polarities. Certainly, creativity has been seen for much of the duration of the academic study of creativity as concerning an individual's character traits, precisely the approach of J P Guilford and E P Torrance, who are regarded as the founders of contemporary academic consideration of creativity. Much has simply followed them from 1950s USA forward in time and across locations. Both authors perceived creativity as deriving singularly from individual character traits and were concerned about measurability. Both were concerned to devise psychometric tests for individual creativity, e.g. Guilford (1950) and Torrance (1974), or that might imply creativity or predict it. Divergent individual thinking was taken as a particular indicator.

The environment within which the individual thinks went unconsidered. That includes both its effects on the individual in an "individual" pursuit of creative aims and ideas, and the notion that creativity can be generated by groups, knowingly and unknowingly. Externalities (to the individual) are important (Amabile, 1983). The composer Tchaikovsky gave a simple example 
in railing about the negative consequences of being interrupted whilst composing (Tchaikovsky, 2004).

In fact, Amabile and Pillemer (2012) conceded that, "examination of social and environmental influences on creativity has become increasingly vigorous." Sternberg's work is often cited as a good example of this slow creep. From 1991, he was proposing (Sternberg \& Lubart, 1991) a confluence approach in creativity. Six distinct resources come together to produce creative outcomes, with those including environment. Environment is seen as "an environment that is supportive and rewarding of creative ideas" (Sternberg, 2006), so very much focused on the surrounding human landscape of support, feedback and reward, which might be a very limiting view of "environment."

A point is still missed, that of the human landscape also contributing ideas as opposed to just supporting the creator and his or her ideas. Cocreation has to be brought forward. Kucharska (2017) has considered cocreation within companies where there are high levels of trust and, thence, collaborative inclination between individual employees. The same can happen between businesses (Baljko, 2010). Collaboration has become a key concept in advanced supply chains, but the focus has been on matching demand and supply (Fisher, Hammond, Obermeyer, \& Raman, 1994) through such devices as real-time data transmission across a transparent supply chain. However, there are many possible levels of supply chain involvement, structure and structured access. At the highest level there can be strategic collaboration, in product design and re-design, e.g. Apple and Foxconn. Freda Yuan of Origin speciality roastery and coffee shops has said, "By working directly with the farmers, we can create a supply chain that is not only sustainable, but develop a relationship that can enhance the quality of the coffee produced" (Yuan, n.d.). Normal collective practices and co-creation are concerned to increase cupping values and relate well with customer flavour preferences. Union Coffee put it thus: "We call ourselves Union because we couldn't make great coffee without our partners - the farmers that grow the exclusive gems we share with you. In return, we pay them a fair price so they can invest in their farm, families and workers. We work with our partners long-term, towards constantly improving the quality of coffee and livelihoods." ("Hello, we're Union Coffee"). However the researchers' contention is that speciality coffee presentation, origin and bean focus, roasting levels, premises décor, come out of informal contact as much as formalised relationships, not to mention internet use and magazine reading reaching a wider group of "speciality coffee people." Drift magazine is something of an industry bible. A face-toface example is that of Jasmine of Lunabar, Penang and Joachim of Spacebar, Penang using each other's coffee shops, attending with friends, talking about coffee but also about anything else friends talk through. They cross-pollinate 
and they co-create. The latter is exampled by combined weekender trips for their clients, and, of course, white décor

Turning now to Passion it must be emphasised at the outset that the academic literature on Passion is often confused, particularly failing to distinguish properly between Passion and Creativity. A robust clarification is required that Passion and Creativity are not one and the same. Passion acts on motivation (e.g., Kunat, 2018). Passion is taken to refer to a strong need for action deriving from personal likes and considerations of importance, so motivating huge investments of time and effort (e.g., Vallerand, 2010). Vallerand's Dualistic Model of Passion (e.g., Vallerand, 2010) posits harmonious passion and obsessive passion, the former referring to a passion that is within the subject's control, chosen freely and balanced with other aspects of life in working toward positive and satisfying outcomes. Those passion-derived work processes might be considered as creative. New ideas and innovations are triggered. Passion stimulates entrepreneurs to overcome challenges and to stay engaged.

All this said, Cardon, Wincent, Singh and Drnovsek (2009) claim that the literature to that point had been unclear in several ways, for instance discovering and outlining processes by which outcomes are influenced by passion. Some writers have, in considering process pressures from passion such as working long hours (e.g., Bird, 1989), might even have discovered a negative.

Cardon et al. (2009) are disposed to consider positives but see positive passionate feelings as deriving not from inherent disposition toward those feelings, in other words a trait, but arising because entrepreneurs are "engaged in something that relates to a meaningful and salient self-identity for them" (Cardon et al., 2009). It follows that Cardon et al. (2009) consider entrepreneurial role identities that might offer such meaningfulness and salient self-identity affirmation to individual entrepreneurs. They suggest three such role identities, that of an inventor, that of a founder and that of a developer. Inventors are passionate about identifying new opportunities and responding to them. Founders' passion is for the founding of businesses to exploit and commercialise around opportunities, creating a business venture. The developer identity is concerned with growing the business once it has been created.

Watne et al. (2012) carried the three Cardon et al. (2009) entrepreneurial role identities forward into their work on craft brewers. Watne et al. (2012) see as critical the notion that passion is not inherent in some entrepreneurs, arguing that "passionate craft brewers may not be passionate people per se, or even passionate about the beer but relate this with things that are important to them such as art and craft, being a trendsetter and connoisseur or gastronomy in a wider sense" (Watne et al., 2012). Elsewhere, Watne 
(2012) argues that the craft brewers see themselves as craftsmen and women first, focused on the art of brewing. Running a business is purely secondary.

Now, referring to the Cardon et al. (2009) entrepreneurial role identities, there will be greater or lesser truth in those between individual entrepreneurs and there may be changes in individuals' views over time. An example is that a passion for opportunity recognition may motivate the entrepreneur toward the creativity of new product development. Creating new beverages may grip the craft brewer or the coffee-shop brewer/roaster. The question is the extent to which private passion can translate into viable business enterprises. There are indications that an important element here is the extent to which the entrepreneur can educate consumers. Concern to educate was a major concern of participants in the current study and was also a significant participant focus in the Watne (2012) craft brewery research. Additionally, the seemingly key element of a supportive environment, perhaps shared local passion (Bhansing et al., 2017), is something the speciality coffee entrepreneurs in this study go out of their way to create, and create also at many levels, from owners supporting and advising each other to, in fact, arranging meet-ups between their customers as mentioned.

\section{RESEARCH METHODS}

At inception this study's research question was simply "What motivates speciality coffee entrepreneurs to start and continue their businesses." The study evolved speedily to also cover what were and are the speciality coffee entrepreneurs' attitudes, with attitudes considered sometimes in quite specific terms, such as attitudes to Instagram or, rather more open-ended, attitudes to risk. A particular concentration of the study and its questions though lay in considering passion and creativity, primarily in an attitudinal context. From inception, the study was also to have a comparative regional element, data being collected in Bangkok, Thailand and Penang, Malaysia.

A constructivist paradigm was chosen for this study. It is aimed at accommodating the complexity of reality, or, more accurately, different realities between different people and groups. It is particularly apt for the current study to be concerned to find as much as possible of the realities of, say, one coffee roaster as against another. One may have a top-line Probat coffee bean roasting machine, another a tiny $1 \mathrm{~kg}$ machine where it is hard to get an even roast, hard to satisfy customers, and hard to roast enough bean quickly enough to meet the demand.

With its aim of searching out case study rich detail, methodologically, this study opts for the duality of a phenomenological approach and inductive 
reasoning, as Braun, Clarke, Hayfield and Terry (2018) have dubbed it "a bottom-up approach." Findings are allowed to emerge, rather than being imposed by the researcher. No hypotheses are offered, conclusions arising purely out of the data. Descriptions are kept as faithful as possible to the raw data. Choice of such a qualitative approach is particularly appropriate to understanding different perspectives, such as those of professionals and patients. Data was gathered by individual interviews of owners/managers/ roasters in speciality coffee retail in Bangkok, Thailand and Penang, Malaysia. Ten interviews were conducted in each of Bangkok and Penang, a total of twenty interviews. The sample size was determined by "contextual and pragmatic considerations" (Braun et al., 2018) meaning that ten was the maximum total number of speciality coffee-shops in Penang, without straying from any reasonable definition of speciality coffee. Participants were to some extent solicited from coffee shop/roaster entrepreneurs already known to the researchers, to some extent using internet search and substantially adopting snowball/chain recommendation. The last was done as a balanced conclusion, successful in its outcomes. The advantage is that the recommender has knowledge of the researchers and their requirements and of the potential participant's ability to contribute. The worry is that the potential participant and referrer simply think in the same way on the topics involved. Such worries made the researchers particularly concerned with emerging themes and so to mobilise thought across categories, questions and answers to that end, throwing up, for instance a range of business Human Relations (Personnel) concerns.

Questions were semi-structured, inevitably with some degree of variability in how structured they were, given that the question set was aimed at being highly comprehensive. The worry is that where questions are more closed, themes develop simply out of the data collection tool, the question. Indeed, Braun et al. (2018) hold that often themes arise out of data collection tools, including the questions. The researchers sought to avoid that, otherwise there is a replication of the deficiencies of quantitative methods. Broadly, the researchers proceeded by Reflexive Thematic Analysis. There was a particular concern to look for missing information, what was not said (Ryan \& Bernard, 2003), which for example proved especially important around entrepreneurial passion.

Data was held within the Quirkos Computer Assisted Qualitative Data Analysis software. The concern was, following Najda-Janoszka and DabaBuzoianu (2018), to hold data in a well-organised, easily retrievable way, representing a clear audit trail of the researchers' work. Quirkos was not used to analyse data or develop categories or themes, those being done manually. Text analytics proceeded from basic word and phrase search. For instance 
"happiness" arose as a category out of noting the repetitive use of the word "happy" or "happiness" singularly or within phrases, but also out of cognates such as "having fun." This particularly concerned answers around why the business is continued but these words also appeared throughout the interviews, for instance, in answering that those participants preferred happiness to riches out of a worldview that clearly saw the two as dichotomous.

\section{ANALYSIS}

Two over-arching themes for the analytic stage of the study were directly suggested by the research questions: Motivations and Attitudes of the speciality coffee entrepreneurs. Multiple categories emerged from the interplay of questions, subsidiary questions and participant answers. For ease of comprehension though, all categories are stated below through questions even if the category arose out of answers.

The basic demographics of gender and age may help the reader to picture the study's entrepreneur participants:

Table 1. Gender and Age of speciality coffee entrepreneurs interviewed

\begin{tabular}{lll}
\hline & Bangkok & Penang \\
\hline Gender & 7 Male, 3 Female & 9 Male, 1 Female \\
Age & Age range: 28-36 & Age Range: 32-46 \\
& Median Value: 35 & Median Value: 33 \\
& Modal Value: Both 32 \& 35 & Modal Value: 32 \\
\hline
\end{tabular}

The arrival of the entrepreneurs into the coffee business was very much out of coffee interest rather than business interest. Some had been avid coffee-shop users, others home brewers. Travel-based narratives were also quite common. Entrepreneurs, on returning home, missed the coffee styles they had found or had worked in the coffee industry whilst travelling. A simple travel support mechanism sometimes became an interest or even a passion.

\section{Motivations}

Why did the entrepreneurs start their business? (Note that individuals might have offered more than one narrative)

To Become Rich? No (eight Bangkok Participants and nine Penang Participants: "Not. Definitely not. To me coffee is not a good way to become rich." "Not really. If you want to be rich you don't like invest in F \& B (Food and Beverage). 
I don't think it will make you rich unless you do volume." "No. I would have stayed in the bank or I would have worked for my parents" "Not make me rich but make me happy." "So if I'm interested in business and money, I won't get into this business. I go into property." "No. For the beginning not really because we came like, what we want to do, our passion..." "I think the coffee business, it's not make money too much." "Not really. Money isn't everything. I'm happy where I'm at, if I have a roof above my head, if I have food, if I can travel, that's it, that's all I need. I can have a bit of savings, that's it" Maybe (two Bangkok, and one Penang Participant) - "I think richer." "I started making coffee to be rich, but we're still figuring out how?"

Travel-based Narratives (three Bangkok Participants and four Penang Participants): "We went to Japan, saw how they did coffee, how they run businesses, how the level of hospitality can be like there to a point of ... It's just a bit absurd. We came back and we tried to do coffee pop-ups around Kuala Lumpur for a year." "That time in Taiwan I was academy. I start my coffee journey. I think six years, six to seven years, I learned about coffee. I resigned my job from the country. Then I come back to Malaysia. I tell myself what can I do? Maybe we can try the coffee shop ..." "I studied abroad before in London, and then I try many coffee in there, so I feel like all of these coffee is good as well. So I think, when I come back and then I try to drink coffee same as I couldn't find, so I couldn't have my perfect coffee in Thailand, so I just tried to, okay." "From the beginning, me and my girlfriend, xxx, so we want to join... They have, working and holiday visa to Australia .... Okay, and then we learn it (coffee) and we joy community everything over there. And after four years in Sydney and came back here and we want to do something about... I mean continue to do what we love to. And yeah, that's why we start to looking for the place to set up the shop and try to educate about what we learn."

Coffee Passion Narratives (six Bangkok Participants and three Penang Participants: "I turned my passion into a business." "So we fell in love with coffee. After that, we, my partner and I, my friend and I, we decide to open a coffee shop." "Because I like to make coffee. I like to make the coffee for other people No. I think it's my passion."

Home Brewer Narratives (two Bangkok Participants): "I used to brew coffee at home, like as a home brewer. I started out as a home brewer, and one of my experiments got into the coffee industry........ Yeah, because I loved to do that, every morning, so it's my ritual. So I made it my business." "I was into coffee, I was brewing at home. I felt I was quite good at brewing drip coffee. Then I opened a shop." 
Sociability (one Bangkok Participant and one Penang Participant): "And the good conversations we have, and how they become my friends" "...and the purpose, we opened this xxx Café is, we like to let people with different backgrounds meet each other."

Like Food and Beverage (two Penang Participants): "Firstly it is why am in this coffee business. I like F \& B." "So over the years I've always liked the F\&B. It doesn't have to necessarily need to be a café. I worked in pubs, restaurants, but it's always been the food and beverage scene."

What stimulated entrepreneurs most when starting their business? (following the Cardon et al. (2009) entrepreneurial role identities of Inventor (Opportunity), Founder and Developer.)

Opportunity (two Bangkok Participants and three Penang Participants): "I interested in the opportunity first. Because if you have the opportunity, maybe you will have the goal." "The opportunity to create things." "The opportunity came about eight years ago, whereby I was given a chance to open a shop myself. I said, why not? I'm just giving it a go."

Founding (two Penang Participants): "When I started. I think, when I started the idea of founding the business stimulates me most." "Renovation."

Developing (eight Bangkok Participants and five Penang Participants): "I think developing. While I'm in the business, I try to look for the flaws, or what I can improve on, and what would be fun. This is the charm of having a small business because you can custom it." "Yeah, developing the business because when I founded the business I have no idea which direction I should go." "It's exciting to see a path through the wilderness, the jungle."

\section{What causes the entrepreneurs to continue their business now?}

Three clear categories emerged from the data, though there were individual outliers:

Learning (four Bangkok Participants and four Penang Participants): "Just learn more about coffee about business." "It's like you'll be, always be a study, maybe you can get something new to learn by yourself. By your friends, by our roaster, by the... It's kinda a lot of knowledge. You can continue learning." "To improve that everyday.....In coffee business, in coffee itself, there's no end. Something like wine, there is no end. It's everything is developing quickly as 
well so you need to catch up and you can't stop, you know what I mean. And so that's why you need to continue."

Happiness (four Bangkok Participants and two Penang Participants): "Because I'm happy." "Because I like it. It's something that I've been sticking to for the longest time in my life." "I'm having a lot of fun." "I think I continue my happiness." "My key ...... My happiness."

People (staff are covered separately) (one Bangkok Participant and three Penang Participants): "We love the vibes. After we open the coffee shop, we have our customer, and our customer become our friend." "It's already a part of my life already. It's not about ... business is a part of what I'm doing now. Like coffee and people. Like I think coffee is the main thing, because coffee bring me to lots of places and bring me to meet a lot of people." "Really, for me, it's always been about the people. As much as I ... We can go really geeky on coffee or how obsessed about coffee. With me there's another level to it, which is another compartment of it, which is the people."

What stimulates entrepreneurs most about their business now?

Two major categories emerged, Learning and People. Six Bangkok Participants and five Penang Participants were people-focused. This category broke down further as below:

People - Customer Interactions: "And the good conversations we have, and how they become my friends." "The customer make me excited somehow, yeah, so we meet many new people, we meet many friend from first is customer, and then they live around here, then we come and now they become friends, and then we say hi every day." "People. People, mostly people. Yeah. People who come to put up their works here. People come to drink coffee, who start talk to us."

People - Customer Education: "Maybe if I find to convert a non-coffee drinker, or like a dark roast drinker into a ..(light roast drinker)." "For the other people, I'm very excited. First, one month to eight month that I open, I talk with every people. I have the bean. This taste like this, taste like this. I have the second bean, it taste like this. From Papa New Guinea, from Laos, from Brazil, and it's like the shared educated. Yeah. I really excited now. All my customers come here and ask today, "Are we speak again?." "It's about educating people about the coffee." 
Learning (solely put forward by three Penang Participants): "Able to discover the more detail in coffee." "There's a lot of knowledge in coffee. There's never an end." "The research still, understanding, learning everything. We still learning everything from mechanical, fluid dynamics, we learn about fluid dynamics, we learn about the electrical system, about machines that make coffee, because we can tweak and modify machines to make the same coffee tastes a lot more better without incurring additional costs on the ingredients."

Additionally, there was a category of those enthralled by the coffee industry. There were many individual outliers, covering for instance the thrill of reaching for business sustainability and an ongoing thrill of invention around new recipes, new beans, etc. Another outlier was one Bangkok participant who had become fascinated with marketing.

The Coffee Industry (solely put forward by two Bangkok Participants): "There's never stop. The new invention and everything. When I first making coffee, there is nothing much about the equipment about making good coffee. Now is hundreds of new espresso machines. Hundreds of brands. A lot of new inventions that make a very good and consistent coffee. There is a lot of a better grinder every year and every year." "We want to put about our industry, about our mind frame business to be the goal, you know.... That's why it's still exciting."

\section{Attitudes}

Is the entrepreneur a Risk-taker?

Yes (five Bangkok Participants and five Penang Participants): "Yeah, I think I take risks." "You have to be. Sometime we try (to reduce risk) but sometime you have to trust what you do right now. We make good coffee. People trust us." "Sure. Why not? Life's short." "Yeah, I think so, I mean opening this space was a big risk, in Thailand. I think that answers the question." "Well, if I'm not I'm not going to start a coffee business." "Yeah, I would say so.... When I started xxx (name of coffee shop) I was halfway doing my masters and I got scholarship for my masters.... I took the scholarship and paid for the startup of the café, the business." "I'm a risk taker. Maybe in certain stuff which we're not sure whether will sell, but we do our research. We do our research. We do measure risk... Mitigate. Don't over commit either ... For example, we took in some analogue cameras we're not sure whether they'd sell, we took in some stickers but in a way we mitigate each other's risk by consignment 
basis." "Yes, absolutely... We do a lot of SWOT analysis. We do SWOT analysis, and then we look at the potential troubles."

Medium (three Bangkok Participants and five Penang Participants): "Ah, 50/50. Because now if only me yes, I'm a risk taker. But now I have my wife, and I plan to have some children in two or three years." "Not risker and not ... Maybe $60 \%$ in the take-risker side. But another $40 \%$, I still conservative." "Medium... Because I'm not very rich .... If I'm very rich, I can take more risk." "I would say sometimes, not all the time." "Sometimes yes, sometimes no.... Yes and no. Depends on the situation. You know." "Yeah, sometimes. Sometimes. Sometimes as you go further, the risk that you take is lesser. Because you have that fear of losing all that you have built up."

No (two Bangkok Participants): “No. Yeah. I'm stressed. No. If you can see my accounting balance .." "For me personally not really."

Is the entrepreneur Passionate about what he/she does?

All ten Bangkok Participants agreed and nine Penang Participants agreed they are passionate (one Penang Participant was missed), though one Penang Participant felt she is substantially more passionate about travel: "I think it's my passion." "Definitely we passionate about it. And we think we must start doing this. "I have passion, passion to make (coffee) because you own farm is amazing if you found some good coffee bean...... We want to put the about the Thailand specialty coffee in the states, we need to be profitable........Yeah, yeah, that's our passion. Yeah, yeah, that's why. It's a lot of passion." "I'm passionate about coffee!"

\section{Is the entrepreneur Creative/Innovative?}

Eight Bangkok Participants agreed the proposition, for one the proposition being inappropriate to his business as he slowly transitioned to speciality coffee, so one Bangkok Participant felt that he had not been innovative. All ten Penang Participants agreed to having been creative/innovative: "With regard to roasting, I roast a different style. I was roasting coffee that people don't usually roast. That was one of the things I wanna do, I want to have a niche, like hey, I'm gonna use this coffee because nobody else is using it." "My signature drinks......... The Cups ......... And then it also gives different taste, with different materials, the thickness." "the most small innovation that we have here in $x x x$ (name of coffee shop) is the fact that we serve churros." "When I roast my coffee, when I brew the coffee, it's have a little 
thing to do different and I think I have the innovation inside that. Different to another mass coffee shop. When I roast the coffee, you control the sugar inside. You can control the amino acid inside...... Another coffee shop, you just roast. Just roast. But we control the sugar inside. It mean you control the acidity, you control the taste inside that." "We bake small cakes because we think that sometimes people, they just want just one or two bite of the cake, and to fulfill their need. Or sometimes they want to try many types of cake, but it's too much. So we make the cakes small. So, you can eat it without guilty!" "Our shop is a combination of many little innovation. It's nothing big. Nothing world changing. So we are constantly looking for minor things to improve. Anything that can improve a customer experience

So we also innovate on our water system before the coffee machine that goes between the water source from the wall, and the espresso machine there's probably eight water filters. There eight different systems there, each one doing specific things, for number one consistency in water quality. And we have inline live water hardness meters that basically tell us what the position is on a daily basis, hour by hour basis .... We sterilise our water."

Does the entrepreneur want to educate people about coffee?

All 20 participants agreed they want to educate about coffee, (ten Bangkok Participants and ten Penang Participants): "On the education side, we educate the customers by creating an opportunity for them to experience coffee in a different way and self-discover. For example, we serve a coffee, we brew a filter coffee, but we serve in three different cups. We tell them, try the coffee in three different cups. And then try to coffee at different temperature. So what we created them is for them to experiment, the experience on the table themselves. That indirectly, they will gain an educational value." "I wanted to educate people over here, let them know what is coffee......... they don't know what is it. I'd like to let them know it's from a fruit. And I like to tell them the health benefit, everything good about coffee." "My planning for the develop my business is about educate the people."

Is the entrepreneur concerned for his/her staff and over staffing (HR/Personnel concerns if any)?

One Bangkok Participant was concerned about these issues (specifically concerned for staff welfare) and seven Penang Participants were concerned about these issues (five concerned for staff welfare and two concerned about staffing): "I hire the staff, I hire like from zero, so I wanted to see their progress.... Yes, because staff is more important than my customer. If my staff 
don't know anything I can't get my customer." "We said we fine if we have one small roaster and one coffee shop. Me and my partner we're totally fine; we can live with this. But for our barista, our employee and everybody, they need to grow up. But if business same size, they never grow up." "At first, we really concerned for our product, the coffee, our coffee shop and everything. But now it's more we think more about the people. The people who work inside the company." "We try and give the dream job we wanted to our staff, to our team." "Especially on the HR things. The most toughest thing in F \& B." "How do we manage the workload of our team to be as low as possible? So that number one, we can possibly cut one staff, not have hiring additional staff. Number two, they have less workload, that means less stress. Then, with an extra time on their hands, we can move them to do better work, focus on different things. That gives high value to your customer."

Does the entrepreneur believe that coffee knowledge among staff is important to the business?

All ten Bangkok Participants agreed on the importance of coffee knowledge and the nine Penang Participants asked also agreed, but two of the Penang Participants qualified their agreement ......... : "Yes. I think it's really important." "Yes ...It's not like come and go anymore. You explain all the menu that you have or maybe the things that different from the other shop." "Yeah. They want to know many things. Sometime, some kind of new question that come from customer, after that at night I have to come to do some research that, what was this about" "Well, most of the people who once have been the café, and if they know me, they will come and talk to me for hours and hours." Note that some entrepreneurs who agreed the importance of knowledge had concerns, for instance around intimidating customers, or around mis-information eg "Yeah, because you have so much knowledge, but if you do not convey it's still a bit slightly pointless. It's too technical. Sometimes you need to slowly know how to pass the message, in terms of layman term. So it helps the consumer too, because when some people they have a lot of knowledge but they don't know how to present it. They don't know how to simplify it, in layman terms."

What is the entrepreneur's view of coffee's Third Wave and its various elements?

Customer Service Nine Bangkok Participants and eight Penang Participants put forward customer service as the key element in Third Wave coffee: "Yes... I think our customers who like drinking coffee come to our shop because they want to talk about coffee... And they're enjoying when I give them knowledge 
about coffee and discuss about taste." "Because people, I believe the service is more impact than the product for me." "That's why about the Third Wave Coffee. For me, right now, about customer service, it's more important than the science of." (a scientific approach has been another characterisation of Third Wave coffee) "I think first is service." "We go to cafes because of interaction with the crew or with the baristas or whatever. So if the first impression, the first interaction is bad, I mean even your food is very good, it's very hard to recover back that part." "Customer service, I think this is very important. The first 30 seconds that someone has to acknowledge, even though you are waiting in line, just to acknowledge that you have come in."

Roasting Two Bangkok Participants saw the Third Wave as about changed roasting levels, though one saw that as a major secondary factor: "Maybe it's like, to me, is Third Wave, Fourth Wave, new generation. I think it's a trend. The coffee tries to change from a very dark roast and try the new way of roasting."

Technical Innovation One Penang Participant suggested technical innovation as the most important element in Third Wave coffee: “... the most important thing that you can see in Third Wave coffee is from the farm, from those people that grew your coffee."

Does the inside/outside of the premises and/or the coffee need to be Instagrammable?

Concerned to be Instagrammable Six Bangkok Participants and nine Penang Participants were concerned: "The social media is so essential in promoting a business, even if the coffee is good, that is." "Instagram is a marketing that need but product always be the number one priority for customer to come back". "Yes, it makes it all memorable, nice, whatever the words are, and gives a social media presence." "Yes now, but in the past, no, and that's because of a changed customer demographic, younger basically, as the years have gone by and the interaction of that youth with social media."

Not concerned to be Instagrammable Four Bangkok Participants and one Penang Participant were unconcerned about their Instagram profile: "No, the accent is on coffee. As in quality, not pictures."

Which is better, a big or a small business?

Small (seven Bangkok Participants answered small and seven Penang Participants answered small): 
"I think it's a small business, yeah...Because it feels more genuine, more true. Yeah, and you get to know all your staffs, and you know them." "Always small." "I would say small businesses is better because we need to take care of a lot of different portion. We need to control the quality, our customer, our staff, and our menu." "Of course a small business...It make it easier to manage and even we want to try something new, I mean, the response is immediate.......No, takes months or years" (big corporation). "Yeah, small business." "The right answer, which is, we like to keep it small. We like to close early, enjoy the rest of our day off, time off." "To me, if big business, I couldn't interact or communicate with my customer." "Small business is the best in the moment...You can more flexible to change anything. There some company is a really big business. If you want to change a some small detail, you have to wasting your time. You need a more than three month, more than a six month. If you need a small change, yeah, it's not good. Change, it's really easy." "Small...We may do a bit bigger, but that's it. Maybe like just a little bit bigger...And we are happy with that, for life." "I think a small business.... It's easier to control what you give, the service you provide. So I think that is better than making it bigger." "... I enjoy small shop. I think the charm of the smaller shop is ... You can see the owner of the place making coffee." "I happy about the small...Yeah, because I think the owner or the barista I want to the coffee to serve it to customer myself." "Small.". "Small." Don't know Three Bangkok Participants answered "don't know," as big is outside of their experience.

Depends on the aims of the business Two Penang Participants suggested this proposition: "It depends on what your angle is."

Table 2 gives a summary of key data gathered.

Table 2. Key Data Summary (Bangkok and Penang Combined)

\begin{tabular}{lll}
\hline Positive response (20 Participants) & Negative response (20 Participants) \\
\hline Attitudes & $20 / 20$ & \\
Want to educate about coffee & $19 / 20$ & $19 / 20$ \\
To be knowledgeable (self and staff) & $18 / 20$ & \\
Passionate & $17 / 20$ & \\
Creative & $14 / 20$ & \\
Customer service concerned & & \\
Small business better & \multicolumn{2}{c}{ To become rich } \\
Motivations & $13 / 20$ & \\
& $11 / 20$ & \\
To develop the business & & \\
People (customer interaction and education) & & \\
\hline
\end{tabular}




\section{DISCUSSION}

Generally, whether considering motivations or attitudes, there was a high level of consistency between answers from the Bangkok and Penang speciality coffee entrepreneurs. For instance, on educating people about coffee, all participants across both locations agreed this was an aim. On coffee knowledge, ten Bangkok Participants and nine Penang Participants saw this as important to the success of their business around customer interaction and service. Nine Bangkok entrepreneurs and eight Penang entrepreneurs framed the coffee Third Wave in terms of customer service, amid a plethora of possibilities. In fact, high levels of customer service came over as a main concern of these coffee entrepreneurs, perhaps the main concern, including that seven participants in each location, responding on the question of big or small business, offered small as their preference. That choice was essentially decided by the high levels of customer service enabled in a small business and also that it means process is enabled that can react quickly to the benefit of the customer. Even where responses between the two locations were quite different in terms of absolute numbers, mostly the overall conclusions would be the same. For example, on the question of Instagram, only six Bangkok entrepreneurs saw the media platform's role in the business as important and to be encouraged, whereas as many as nine entrepreneurs in Penang "voted" that way, quite a difference, but in both locations a "yes" to the importance of Instagram was the majority conclusion. Exceptions included concern around staff welfare and concern around staffing. Penang Participants dominated interest in these topics in the ratio 7:1. The stimulant of learning about their business now was only suggested by Penang Participants (3).

Clearly, these entrepreneurs were not in the speciality coffee business in the expectation of becoming rich. That area of questioning became something of a joke, though one that had to be asked. They were also, in both Bangkok and Penang, looking to keep their businesses small, expressing advantages in customer service and flexibility of decision-making and action in situations arising. The speciality coffee entrepreneurs are pursuing a lifestyle choice. As one said, financially she would have been better staying working with her banking employer, another that he would have been better off investing in property. But those approaches did not accord with their lifestyle choices. Indeed, ten Bangkok Participants and nine Penang Participants readily agreed that they were passionate, motivated by passion and the specific word "passion" arose a lot in interviews. But the question is passionate about what? The answer appears not to be entrepreneurialism, not to be business, but, simply, to be coffee. The researchers, therefore, see this study exactly as Watne (2012) argues for his craft brewer participants, that the speciality 
coffee entrepreneurs see themselves as craftspeople and running a business is a secondary consideration, albeit that there was some evidence that aspects of running a business may gain some interest traction with time, an example being a concern for staff. James Hoffman, a well-known speciality coffee entrepreneur and writer working out of London, put it thus when talking about Square Mile Coffee Roasters: "It was a business that was started from a place of passion but not a great deal of business knowledge - which we've worked hard to rectify since" (Langlois, 2019).

It is worth considering how far that coffee passion can run. One participant explained how coffee had become his life. His friends are all from the coffee "scene." "Like actually coffee gives me a lot of like my life, it's become my life....Yes, I go holiday, but 50 percent of the time I would spend in the cafe for the coffee." A passionate, embedded life, but one very interesting to consider from the viewpoint of creativity. Are these entrepreneurs so embedded in speciality coffee culture as to be closed to other ideas, other inputs available, in fact specifically from outsiders to speciality coffee culture and the speciality coffee tribe? Certainly the entrepreneurs seemed to have their own answers. Creativity and innovation were defined as being very much related to their times abroad, working, studying, holidaying, being a coffee shop user. Ideas (for instance around customer service), processes (for instance coffee roast levels or "pour" types and styles) and décor (white) that they were adopting were seen as creative/innovative but only to the extent that these were found abroad and brought back to Thailand and Malaysia from Australia, Taiwan. Korea, Japan and the UK, and are in contra-distinction to traditional coffee shops in both Thailand and Malaysia. In fact, in the researchers' view, the rate of adoption of these outside influences has been such that they now constitute a part of the local speciality coffee tribes' culture.

The researchers feel that any automatic or near automatic presumption of passion and creativity being bedfellows is naivety in the extreme. In their view, creativity arises specifically out of a relatively unsocialised position (Gogatz \& Mondejar, 2005) or more accurately, for adults the ability to emulate one as best possible, assuredly the opposite of tribal cultures, however, contemporary their outlook and however well-travelled their membership. The deeply supportive and highly networked inter-business relationships in Bangkok and Penang, and between the two, may not be as beneficial as seems at first sight. The need is to be highly suspicious of the theoretical work of Sternberg and Lubart (1991) on supportive environments, essentially meaning human landscapes, as it is at least ignoring negatives. The same may well be true of the work of Bhansing et al. (2017) on Creative Business Centres. Where these Centres are less limiting than simply entrepreneurs' peers within an industry, in that they embrace entrepreneurs from a number 
of business areas, those may be highly cognate, often creative businesses, with similar ideas. Put at its simplest, how do you think outside of the box when doing your best to contain yourself within it? At best, you can become co-creator of a new normal.

\section{CONCLUSIONS}

There were no hypotheses in this study. It was based on the phenomenological proposition of giving the participants a voice as they chose, albeit that semistructured questions from the interviewer acted to instigate the discussion. No answer was the wrong answer and no comment in conversation was inadmissible. Despite the open-ended nature of questioning and responses, this study, on balance, indicated similarity rather than difference between the speciality coffee entrepreneurs' responses in Bangkok and Penang to a range of core questions, both about their business and entrepreneurship in general, particularly in the business start-up phase but also the early years.

The researchers' questions included why did entrepreneurs start their businesses or why do they continue their business, along with such questions as what excited them most at start up and what excites them most now. Equally, a range of questions aimed to elicit entrepreneurs' views around and exampling of passion and creativity. Across this wide breadth of questioning the similarity in answers kept showing even in such areas as Third Wave coffee where the range of possible individual interpretations is nearly endless. Similarity could also be seen with previous work on craft entrepreneurs, e.g. Watne et al. (2012). Particularly, around the key concept of passion, participants were passionate about coffee's craft skills and processes, though not as passionate about entrepreneurship.

Any limitations in this study were knowingly set by the researchers from the outset in establishing the conceptual framework and, notably, comparative boundaries to the study. No further limitations occurred during the process of the study, for instance, any inability to recruit entrepreneur participants. Bangkok and Penang are major speciality coffee centres within South-East Asia, though Penang, much smaller than Bangkok, did require a high recruitment rate. Nonetheless, only two locations were considered and at a particular point in time, summer 2019, so representing an innate limitation necessitated by the availability of finance, time and manpower. Future research could be undertaken in other speciality coffee centres within South-East Asia, with Kuala Lumpur, Ho Chi Minh City and Hanoi coming to mind. The study might also be extended to cover major East Asian centres such as Taiwan, South Korea and Japan. As the range of centres included 
becomes wider, it would become more possible to consider generalisability or at least transferability, though at this point potential indications across speciality coffee look as though they could be positive. Speciality coffee seems to represent an entrepreneurial niche, similar to other suppliers in artisanal, craft-concerned Food and Beverage.

Of course, this commentary for future research should not though be limited to Asia. Future venues for study could be global, Melbourne or Oslo being particularly obvious examples. However, perhaps this study offers something wider still, in that a takeaway for any student or researcher in entrepreneurship anywhere, should be as seen here that passion in entrepreneurship may not be driven by classical economic components. This consideration has particular value in the craft industry but is also applicable much more widely in an era of social enterprise.

This research also offers a takeaway in practical business terms. Suppliers to these businesses are not dealing with customers within the normal constraints of economic rationality. That must be thought about in product development and marketing to them. For instance, is a more expensive product or service highly saleable to the speciality coffee entrepreneurs, so long as its environmental credentials are very clear? Do financial advisers need to offer non-standard financial advice and specifically tailored financial products? Perhaps financial services need, in particular, to be able to demonstrate corporate social responsibility? What advice should a Government or Local Government advisory service offer to businesses whose framework of reference is so outside the norm?

\section{References}

Arat, E. (n.d.). The history of Turkish coffee. Retrieved from https://www. turkishcoffeeworld.com/History-of-Coffee-s/60.htm

Amabile, T. M. (1983). The social psychology of creativity: A componential conceptualization. Journal of Personality and Social Psychology, 45(2), 357-376.

Amabile, T. M., \& Pillemer, M. (2012). Perspectives on the social psychology of creativity. The Journal of Creative Behavior, 46(1), 3-15. https://doi. org/10.1002/jocb.001

Baljko, J. (2010, October 20). A successful supply chain needs collaboration and co-creation. Retrieved from https://www.ebnonline.com/asuccessful-supply-chain-needs-collaboration-co-creation/

Bhansing, P. V., Hitters, H., \& Wingaarden, Y. (2018). Passion inspires: Motivations of creative entrepreneurs in creative business centres in the Netherlands. The Journal of Entrepreneurship, 27(1), 1-24. https://doi. org/10.1177/0971355717738589 
Bird, B.J. (1989). Entrepreneurial Behavior. Glenview, IL: Scott Foresman \& Co. Braun, V., Clarke, V., Hayfield, N., \& Terry, G. (2018). Thematic analysis. In P. Liamputtong (Ed.), Handbook of Research Methods in Health Social Sciences (pp.1-18). Singapore: Springer Nature. http://dx.doi. org/10.1007/978-981-10-2779-6

Brikci, N., \& Green, J. (2007, February). A guide to using qualitative research methodology. Retrieved from https://fieldresearch.msf.org/ handle/10144/84230

Cardon, M.S., Wincent, J., Singh, J., \& Drnovsek, M. (2009). The nature and experience of entrepreneurial passion. Academy of Management Review, 34(3), 511-532. https://doi.org/10.5465/amr.2009.40633190

Churchard, C., Townshend, G., \& Stone, S. (2018, February 15). Get the picture: Promoting your pub with Instagram. Retrieved from https:// www.morningadvertiser.co.uk/Article/2018/02/15/Get-the-picturepromoting-your-pub-with-Instagram

Fisher, M.L., Hammond, J.H., Obermeyer, W.R., \& Raman, A. (1994). Making supply meet demand in an uncertain world. Harvard Business Review, 72(3), 83-93.

Giljam, E. (2018, February 1). Speciality coffee in Oslo. Retrieved from https:// www.theexploringbarista.com/specialty-coffee-oslo

Gogatz, A., \& Mondejar, R. (2005). Business Creativity, Breaking the Invisible Barriers. London, UK: Palgrave Macmillan.

Goodwin, L. (2019, September 24). The origin of coffee. Retrieved from https://www.thespruceeats.com/the-origin-of-coffee-765180

Green, M. (2013, August 7). The lost world of the London coffee house. Retrieved from https://publicdomainreview.org/2013/08/07/the-lostworld-of-the-london-coffeehouse/

Guilford, J.P. (1950). Creativity. American Psychologist, 5, 444-454.

Hello, we're Union Coffee. (n.d.). Retrieved from: https://unionroasted.com/ pages/about History of Coffee: Where did coffee originate and how was it discovered? (n.d.). Retrieved from https://www.homegrounds.co/ history-of-coffee/

Inwood, S. (1998). A History of London. London, UK: Macmillan.

Johnson, J. (2019, July 31). How to make an Instagrammable café. Retrieved from https://www.freshcup.com/how-to-make-an-instagrammable-cafe/

Kucharska, W. (2017). Relationships between trust and collaborative culture in the context of tacit knowledge sharing. Journal of Entrepreneurship, Management, and Innovation, 13(4), 61-78. https:// doi.org/10.7341/20171344

Kunat, B. (2018). Passion and creativity - together or separately? Creativity, 5(1), 55-71. https://doi.org/10.1515/ctra-2018-0004

Langlois, A. (2019). Momentum. Drift, 8, 40-44.

Morris, J. (2007). The Cappuccino Conquests. The Transnational History of Italian Coffee. Hatfield, UK: University of Hertfordshire. 
Morris, J. A. (2008). History of espresso in Italy and the World. In C. Maurizio (Ed.), 100\% Espresso Italiano (pp.4-32). Trieste, Italy: Antorami.

Najda-Janoszka, M., \& Daba-Buzoianu, C. (2018). Editorial paper: Exploring management through qualitative research - introductory remarks. Journal of Entrepreneurship, Management and Innovation, 14(4), 5-15. https://doi.org/10.7341/20181440

Nzegwu, N. (n.d.). Ethiopia: The origin of coffee. Retrieved from https://www. africaresource.com/house/news/our-announcements/21-the-historyof-coffee

Oden, G. (n.d.). Starbucks vs specialty coffee: What's the difference? Retrieved from https://www.javapresse.com/blogs/buying-coffee/starbucks-vsspecialty-coffee

Ryan, G.W., \& Bernard, H. R. (n.d.). Techniques to identify themes in qualitative data. Retrieved from http://www.analytictech.com/mb870/Readings/ ryan-bernard_techniques_to_identify_themes_in.htm

Sternberg, R. J., \& Lubart, T. I. (1991). An investment theory of creativity and its development. Human Development, 34(1), 1-31. https://doi. org/10.1159/000277029

Sternberg, R. J. (2006). The nature of creativity. Creativity Research Journal, 18(1), 87-98.

Tchaikovsky, M. (2004). Life and Letters of Peter llich Tchaikovsky. Honolulu, $\mathrm{HI}$ : University Press of the Pacific.

The History of Coffee. (n.d.). Retrieved from http://www.ncausa.org/aboutcoffee/history-of-coffee

Theng, A. J. (2018, May 2). Third-Wave coffee, 'independent' sites of consumption and the commodification of authenticity in global cities. Presented at 10th Linguistic Landscapes Workshop, Bern, Switzerland. Retrieved from https://www.academia.edu/36679246/ Third-Wave_Coffee_Independent_sites_of_Consumption_and_the_ Commodification_of_Authenticity_in_Global_Cities

Torrance, E.P. (1974). Torrance Tests of Creative Thinking. Lexington, MA: Personnel Press.

Vallerand, R.J. (2010). On passion for life activities: the dualistic model of passion. In M.P. Zanna (Ed.), Advances in Experimental Social Psychology (pp. 97-193). New York, NY: Academic Press. https://doi.org/10.1016/ S0065-2601(10)42003-1

Watne, T. (2012, December 3). Agents of change: An investigation into how craft brewers educate their customers. Presented at Australia and New Zealand Marketing Academy Conference, Adelaide, South Australia, Australia. Retrieved from https://www.academia.edu/2562282/Agents_of_change_ An_investigation_of_how_craft_breweries_educate_their_consumers

Watne, T., Hakala, H., \& Kautonen, $\bar{T}$. (2012, June 10). Business from passion. An enquiry into the business models of craft breweries in Victoria, Australia. Presented at The International Council for Small Business 
World Conference, Wellington, New Zealand. Retrieved from https:// drive.google.com/file/d/OB9pflhVOKMWBWUFLNUlkMVVJcVU/view Yuan, F. (n.d.). Story. Retrieved from https://www.origincoffee.co.uk/pages/ story

\begin{abstract}
Abstrakt
Cel: W artykule omówiono niedawno powstajqcy przemysł kawowy w Bangkoku w Tajlandii i Penang w Malezji. Zajmuje się on pytaniami badawczymi dotyczq̨cymi motywacji i postaw właścicieli małych, przedsiębiorczych firm kawowych w obu krajach. Metodyka: Metodyka badania polegała na gromadzeniu danych jakościowych na podstawie wywiadów bez z góry określonych hipotez. Wywiady były częściowo ustrukturyzowane. Pytania dotyczyły w różny sposób motywacji i postaw, ale szczególnymi punktami skupienia były pasja i kreatywność. Analiza odbywała się poprzez analizę treści tematycznych. Wyniki: Główne ustalenia były takie, że uczestnicy uważali się za pełnych pasji i kreatywnych, chcieli uczyć się o kawie (pierwsze odkrycie) i nie mieli żadnych oczekiwań ani nadziei na wzbogacenie się poprzez swoje przedsiębiorstwa kawowe. Skupiali się na innych elementach szczęścia niż pieniqqdze. Okazało się, że ich pasja nie była pasjq przedsiębiorczości, napędzanq finansowo, ale pasja do umiejętności rzemieślniczych i produkcji, a także towarzyszqcego im stylu życia, który po prostu nie dotyczył maksymalizacji dochodów. Implikacje dla teorii i praktyki: Przedstawia potencjalny poglqqd na przedsiębiorczość będq̨cy w znacznej rozbieżności z poglqadami klasycznej ekonomii. Niewielu przedsiębiorców, z którymi przeprowadzono wywiady, uważało, że ich firmy maja potencjał tworzenia bogactwa. Obawy o maksymalizację dochodu lub zysku nie były powszechne. Nie byli to finansowo napędzani przedsiębiorcy klasycznej ekonomii. Skupiali się na swoim rzemiośle i jego umiejętnościach. Całe zrozumienie nastawienia właścicieli i twórców małych firm zajmujqcych się kawq jest spostrzeżeniem o istotnym znaczeniu praktycznym, na przykład dla tych, którzy chcq im dostarczać kawę i być może innym podobnym małym firmom, lub aby im doradzać, w tym usługi doradcze dla rzqdu i samorzqdów lokalnych. Oryginalność i wartość: Pytanie postawione w tym badaniu nigdy wcześniej nie zostało zadane, więc badanie jest wyjq̨tkowe w branży. Jego wartość leży w dwóch obszarach: praktycznym, realnym świecie biznesu, jak wspomniano, oraz dla przyszłych badaczy przedsiębiorczości. Ponieważ te małe firmy sq zbudowane z koncepcji stylu życia, a nie klasycznych koncepcji ekonomicznych, zwłaszcza w zakresie maksymalizacji dochodu lub zysku i odpowiedniej skali, istnieje poważna wq̨tpliwość co do ważności tych klasycznych poglqqdów ekonomicznych. Istotnq wartościq w tym badaniu jest właśnie to, że wniknęło ono i uderzyło w mnóstwo motywacji i postaw prezentowanych nieformalnie przez przedsiębiorców.
\end{abstract}

Słowa kluczowe: pasja, kreatywność, kawa, rzemiosło, przedsiębiorczość, umiejętności rzemieślnicze, mały biznes 


\section{Biographical notes}

Mark Azavedo is a Doctoral candidate at Shinawatra University, Thailand, who holds an MBA from Stamford International University. He has been a serial small business entrepreneur in both the business-to-business arena and that of business to consumer, the latter covering many retail formats including pop-up. His main research interests are the food supply chain, and artisanal food and beverage production and marketing. He has written extensively in these areas, always seeking to consider the application of his findings for small businesses, and the suppliers to them, and to consider the social elements in transactions and pricing ignored in classical economics.

Art Gogatz is an Associate Professor with affiliation to Phayao University, Thailand. He is also Director of the World Innovation Team, an international consulting business with bases in Los Angeles, California and Bangkok, Thailand. Art has taught, mostly at graduate level, in thirty-seven countries across the Americas, Asia and Europe. His speciality is creativity and innovation in business. He has authored or co-authored fifty-plus articles and three books on the subject. "Business Creativity, Breaking the Invisible Barriers" (Palgrave/Macmillan) has been translated into Russian and Chinese. Art is a frequent speaker at international conferences on business and education.

\section{Conflicts of interest}

The authors declare no conflict of interest.

\section{Citation (APA Style)}

Azavedo, M., \& Gogatz, A. (2021). The developing speciality coffee businesses of Bangkok, Thailand and Penang, Malaysia. A story of entrepreneurial passion and creativity?. Journal of Entrepreneurship, Management and Innovation, 17(1), 203-230. https://doi.org/10.7341/20211717 